\title{
ARCHIWOZNAWSTWO W XXI WIEKU - WYZWANIA, PROBLEMY, KIERUNKI ZMIAN
}

\section{Słowa kluczowe}

archiwoznawstwo; archiwistyka; przegląd archiwoznawczy

\section{Keywords}

knowledge of archives; archival science; review in knowledge of archives

\section{Streszczenie}

Archiwoznawstwo to dział archiwistyki zajmująca się badaniem historii archiwów, ich współczesnej organizacji oraz historii zespołów i zbiorów archiwalnych z uwzględnieniem ich zawartości treściowej. W związku z powyższym w refleksji archiwoznawczej można wyodrębnić zasadniczo trzy kierunki badań. Pierwszy stanowi historia archiwów jako instytucji, ich zadań, funkcji, metod pracy, personelu, lokali, wyposażenia i wielu innych aspektów działalności. Jako drugi należy wymienić refleksje nad organizacją współczesnych archiwów. Nurtem trzecim są z kolei badania nad zasobem archiwalnym, a ściślej, dziejami zespołów archiwalnych, ich zawartością, rozmieszczeniem. Szczególne miejsce wśród publikacji archiwoznawczych zajmują tzw. przeglądy archiwoznawcze. Są to teksty naukowe stanowiące prezentację, usystematyzowanie, omówienie materiałów archiwalnych - źródeł historycznych dotyczących określonej problematyki, wytworzonych w określonym czasie i na danym obszarze, znajdujących się w zasobie konkretnego archiwum, archiwów lub innej/innych placówek wykonujących zadania archiwalne.

Hubert Mazur. Asystent w Katedrze Archiwistyki i Nauk Pomocniczych Historii na Uniwersytecie Pedagogicznym im. KEN w Krakowie. Autor ponad 70 artykułów naukowych z zakresu działalności edukacyjnej archiwów i archiwoznawstwa.

E-mail: hubert.mazur@up.krakow.pl

ORCID ID: 0000-0002-5578-9251 
Początek XXI w. to z pewnością kryzys archiwoznawstwa, co wiązać należy z upadkiem funkcji opracowania zasobu i regresem w działalności naukowej archiwów. Informatyzacja archiwów i coraz większe możliwości wyszukiwawcze baz danych każą postawić pytanie o zasadność podejmowania inicjatyw na polu archiwoznawczym. Tymczasem bez archiwoznawstwa trudno wyobrazić sobie istnienie pozostałych działów archiwistyki. Wyniki badań archiwoznawczych powinny zaspokajać potrzeby informacyjne użytkowników i stanowić pomoc w realizacji funkcji udostępniania.

\section{Summary}

Knowledge of archives in the $21^{\text {st }}$ century - challenges, problems, directions for changes

Knowledge of archives is a branch of archival science that concerns studying history of archives, their contemporary organisation, as well as history of fonds and collections, including their content. In connection with this, three main research directions might be distinguished as part of the reflection in knowledge of archives. The first one is history of archives as institutions, their tasks, functions, working methods, staff, premises, equipment, and many other aspects. The second one is reflection on organisation of contemporary archives. The third direction is studying archival collections, more specifically - history of archival fonds, their content, and placement. A special place amongst publications in knowledge of archives hold so called reviews in knowledge of archives (Polish przeglady archiwoznawcze). They are scientific texts that present, classify, and describe archival materials - historical sources concerning particular topics, created in selected time on some territory, that are stored in particular archives or other institutions serving archival functions. The beginning of the 21st century is certainly a crisis for knowledge of archives; it can be connected to the decline in arrangement and description, and the regression in the field of the scientific function of archives. Implementation of IT solutions in archives and growing searching possibilities of data bases make us pose the question of justification of archival knowledge endeavours. Meanwhile, though, it is hard to imagine all other branches of archival science without the knowledge of archives. Results of studies conducted as part of the knowledge of archives should satisfy information needs of users and be helpful in providing access to archival materials.

$\mathbb{N}_{\mathrm{i}}^{\mathrm{ie}}$

ie wszystkie dyscypliny archiwistyki rozwijają się w równomiernym stopniu i tempie. Wydaje się, że współcześnie możemy mówić o pewnym regresie archiwoznawstwa. Przyczyna tego stanu leży zapewne w kryzysie naukowej aktywności archiwów. Działalność naukowa archiwów w ostatnim czasie zdaje się przegrywać z ich funkcją administracyjną. Co ważne, pojawiają się głosy, że archiwa w ogóle nie powinny być placówkami naukowymi. Bodaj najbardziej skrajnym z nich jest artykuł opublikowany na blogu „Rotulus”, w którym czytamy: 
„Biorąc pod uwagę, że zapotrzebowanie na artykuły naukowe interesujące zazwyczaj tylko kilka osób, w tym samego autora lub papierowe inwentarze z sążnistymi wstępami (opracowane naukowo) interesują mikroskopijny odsetek społeczeństwa, dziwić musi fakt, że archiwiści otrzymują za swoją pracę jakiekolwiek wynagrodzenie. Społeczeństwo nie oczekuje opracowań naukowych, ale udostępnionych online materiałów, opatrzonych w taki sposób metadanymi, aby można było bezbłędnie do nich dotrzeć. Taka praca ma sens i jest doceniana. Krótko mówiąc działalność naukowa w archiwum w odniesieniu do opracowania zasobu to niegospodarność i w taki sposób powinno się ją oceniać podczas kontroli finansowych tych jednostek budżetowych"1.

Nie bez wpływu na kryzys archiwoznawstwa jest osłabienie roli opracowania zasobu czy ostatnio nawet zaprzestanie realizacji prac na tym polu. Trzeba zwrócić wreszcie uwagę na często artykułowane przekonanie, że archiwa i archiwiści poprzez badania i publikacje archiwoznawcze nie powinni wyręczać historyków w ich pracy. Informatyzacja archiwów i coraz większe możliwości wyszukiwawcze, które zapewniają elektroniczne bazy danych i systemy, każą postawić pytanie o zasadność podejmowania inicjatyw na polu archiwoznawczym. Czy rzeczywiście archiwoznawstwo jako dział archiwistyki musi w XXI w. bezpowrotnie przejść do lamusa? A może jest to dyscyplina niezbędna także dla pozostałych gałęzi archiwistyki - teorii i metodyki? Czy archiwoznawstwo jest potrzebne historykom, czy może okazać się przydatne w bieżącej pracy archiwów? Jak przedstawiają się obecnie badania i publicystyka w omawianej materii? Czy istnieje potrzeba modernizacji i wytyczenia nowych kierunków rozwoju dla archiwoznawstwa? To tylko kilka pytań nurtujących autora, na które postara się odpowiedzieć w przygotowanym artykule.

Dla porządku warto przypomnieć, co oznacza termin archiwoznawstwo.

Polski stownik archiwalny z 1952 r. podaje, że jest to „dyscyplina archiwistyki obejmująca historię archiwów i wiadomości o zespołach lub zbiorach archiwalnych"2.

Bohdan Ryszewski określa je jako „dział archiwistyki, stanowiący naukowy opis archiwów, ich rozwoju historycznego i organizacji współczesnej, kształtowania się i rozmieszczania zasobu archiwów”3.

${ }^{1}$ H. Niestrój, Wynagrodzenie, a praca naukowa $w$ archiwum, http://rotulus.arcaion. pl/archiwistyka/wynagrodzenie-a-praca-naukowa-w-archiwum/ (dostęp: 28.01.2018).

2 A. Bachulski, K. Konarski, A. Wolf, Polski słownik archiwalny, Warszawa 1952, s. 3.

3 B. Ryszewski, Archiwistyka. Przedmiot, zakres, podział (Studia nad problemem), Warszawa-Poznań 1972, s. 93. 
Polski słownik archiwalny z 1974 r. jasno stwierdza, że jest to dział archiwistyki zajmujący się badaniem historii i organizacji archiwów oraz historii zespołów archiwalnych z uwzględnieniem ich zawartości treściowej

Na temat archiwoznawstwa wypowiedział się także Czesław Biernat, który kwestionował potrzebę wyodrębniania go jako dyscypliny archiwistyki. Archiwoznawstwo zajmujące się opisem i charakterystyką treści oraz rozmieszczeniem dokumentacji archiwalnej wchodzi w zakres opracowania i udostępniania zasobu $^{5}$.

Z kolei Józef Szymański jako przedmiot archiwoznawstwa stawia nie tylko historię archiwów, ale także „praktyczną informację o zasobie archiwalnym przechowywanym w poszczególnych archiwach" ${ }^{\text {. }}$

Dla Haliny Robótki archiwoznawstwo „to dział archiwistyki zajmujący się dziejami archiwów państwowych, prywatnych i innych, w powiązaniu z historią ustroju administracji, kształtowaniem się zasobu archiwalnego, organizacją archiwów i opisem przechowywanego zasobu, kształtowaniem narastającego zasobu"

Najnowszą definicję zaproponował Waldemar Chorążyczewski: „Archiwoznawstwo [...] to naukowy opis zasobów archiwalnych wyprowadzony z dziejów archiwów. Ten wątek historyczny, tłumaczący aktualny stan zasobu, często jest tak zawikłany i wymaga tak szeroko zakrojonych badań, że archiwoznawstwo w praktyce sprowadza się najczęściej do historii archiwów (zasobów archiwalnych) i metod pracy w nich panujących"•. Należy zwrócić uwagę na fakt, że Chorążyczewski w odróżnieniu od pozostałych przywołanych wyżej badaczy na pierwszym miejscu stawia dzieje i zawartość zespołów archiwalnych, a dopiero po nich historię samych archiwów.

Nie może być wątpliwości, że ojcem archiwoznawstwa jest Andrzej Tomczak, autor monumentalnego dzieła, czyli historii archiwów polskich, stanowiącego drugą część podręcznika polskiej archiwistyki. Nie zdefiniował on wprawdzie pojęcia archiwoznawstwo, jednak już tytuł pracy Zarys dziejów archiwów polskich i ich wspótczesna organizacja wskazuje jakie obszary stawiał przed tym działem archiwistyki. Były to więc dzieje i organizacja archiwów różnego typu ${ }^{9}$.

4 Polski Stownik Archiwalny, red. W. Maciejewska, Warszawa 1974, s. 19.

5 C. Biernat, Problemy archiwistyki wspótczesnej, Warszawa 1977, s. 34-37.

${ }^{6}$ J. Szymański, Nauki pomocnicze historii, Warszawa 2009, s. 505.

${ }^{7}$ H. Robótka, Wprowadzenie do archiwistyki, Toruń 2002, s. 49.

${ }^{8}$ W. Chorążyczewski, Archiwistyka dla początkujacych, s. 6, https://repozytorium. umk.pl/bitstream/handle/item/2191/Archiwistyka_dla_poczatkujacych_wersja_1.pdf?sequence $=1$ (dostęp 19.04.2018 r.)

9 H. Robótka, B. Ryszewski, A. Tomczak, Archiwistyka, Warszawa 1989, s. 169-171. 
Analizując wymienione wyżej definicje, łatwo zauważyć, że przedmiotem archiwoznawstwa są po pierwsze dzieje archiwów, po drugie ich współczesna organizacja i po trzecie wreszcie zasoby archiwów - ich historia i zawartość. W związku z powyższym w refleksji archiwoznawczej można wyodrębnić zasadniczo trzy kierunki badań. Pierwszy stanowi historia archiwów jako instytucji, ich zadań, funkcji, metod pracy, personelu, lokali, wyposażenia i wielu innych aspektów działalności. Jako drugi należy wymienić refleksje nad organizacją współczesnych archiwów. Nurtem trzecim są z kolei badania nad zasobem archiwalnym, a ściślej dziejami zespołów archiwalnych, ich zawartością i rozmieszczeniem.

Jeśli chodzi o pierwszy nurt, to reprezentują go publikacje syntetyczne poświęcone dziejom archiwów w danym okresie i na danym obszarze. Do klasyki należy zaliczyć tu prace Andrzeja Tomczaka ${ }^{10}$, a także wydane w ostatnim czasie książki Ireny Mamczak-Gadkowskiej ${ }^{11}$, Piotra Majewskiego ${ }^{12}$ i Janusza Tandeckiego ${ }^{13}$. Innym przykładem jest opracowanie Stefana Ciary odnoszące się do określonych aspektów funkcjonowania archiwów galicyjskich ${ }^{14}$. Drugim rodzajem publikacji są prace poświęcone dziejom konkretnych, pojedynczych archiwów, zarówno w postaci wydawnictw zwartych, jak i artykułów naukowych. Dotyczą one archiwów państwowych ${ }^{15}$, wyodrębnionych ${ }^{16}, \mathrm{z}$ powierzonym zasobem ${ }^{17}$, kościelnych (parafialnych ${ }^{18}$, diecezjalnych ${ }^{19}$ i klasztor-

${ }^{10}$ A. Tomczak, Zarys dziejów archiwów polskich, cz. I - do wybuchu I wojny światowej, Toruń 1974; tegoż, cz. II - od wybuchu I wojny światowej do roku 1978, Toruń 1980; tegoż, Zarys dziejów archiwów polskich, wyd. 2, Toruń 1982.

11 I. Mamczak-Gadkowska, Archiwa państwowe II Rzeczypospolitej, Poznań 2006.

12 P. Majewski, Wojna i kultura. Instytucje kultury polskiej $w$ okupacyjnych realiach Generalnego Gubernatorstwa 1939-1945, Warszawa 2005.

13 J. Tandecki, Archiwa w Polsce w latach 1944-1989. Zarys dziejów. Pamięci Profesora Andrzeja Tomczaka, Toruń 2017.

14 S. Ciara, Archiwa a uniwersytety $w$ Krakowie $i$ Lwowie $w$ latach 1877/78-1918, Warszawa 2002.

15 T. Matuszak, Archiwum Państwowe w Piotrkowie Trybunalskim 1919-1951, Piotrków Trybunalski-Radzyń Podlaski 2009; E. Kołodziej, Zarys dziejów Archiwum Akt Nowych w latach 1919-2008, Warszawa 2008.

16 W. K. Roman, Centralne Archiwum Wojskowe 1918-1998. Tradycje, historia, wspótczesność stużby archiwalnej Wojska Polskiego, Toruń 2002.

17 T. Skrzyński, Archiwum Nauki Polskiej Akademii Nauk i Polskiej Akademii Umiejętności. Z przeszłości i teraźniejszości, „Archiwista Polski” 2004, nr 1, s. 17.

${ }_{18}$ M. Hlebionek, Archiwum parafialne w Gietrzwałdzie do 1890 roku, „Archiwista Polski" 2001, nr 1, s. 68.

19 A. Krochmal, Archiwum historyczne eparchii przemyskiej, Warszawa-Przemyśl 2016; 
nych ${ }^{20}$ ), społecznych ${ }^{21}$, rodzinnych ${ }^{22}$ lub innych instytucji o charakterze archiwalnym ${ }^{23}$. Okazją do powstawania opracowań poświęconych historii archiwum są jubileusze utworzenia danej placówki archiwalnej. Częstą praktyką jest, że wydaje się wówczas publikacje naukowe z tekstami dotyczącymi historii konkretnego archiwum, jego poszczególnych funkcji i działalności, zasobu oraz źródeł archiwalnych do poszczególnych aspektów dziejów regionu ${ }^{24}$. Nie wszystkie tego typu wydawnictwa mają jednak charakter naukowy. Część z nich ogłoszona z okazji rocznicy powstania danego archiwum służy głównie uświetnieniu jubileuszu oraz celom promocyjnym i popularyzatorskim ${ }^{25}$. Choć prace takie dostarczają rzecz jasna wiadomości o historii archiwum, trudno je uznać za naukowe dzieła archiwoznawcze.

Jako trzeci typ opracowań omawianego nurtu wskazać należy publikacje traktujące o wybranych aspektach działalności archiwów w przeszłości. Opisują one określone funkcje archiwów w danym czasie i na danym obszarze ${ }^{26}$.

Problematyka dotycząca publikacji poświęconych dziejom archiwów została podjęta przez Tomasza Matuszaka, który uważa, że tego typu badania uzupełniają istniejącą lukę badawczą „z wykorzystaniem dotychczasowego dorobku historiografii, ale przede wszystkim w oparciu o zachowane, a nieznane i niepublikowane niejednokrotnie do tej pory materiały źródłowe". Zaznaczył także, że:

M. Nabożny, Archiwum Diecezjalne w Rzeszowie. Powstanie, zasób i działalność, „Archiwa, Biblioteki i Muzea Kościelne”, t. 97, 2012.

${ }^{20}$ M. Dębowska, Archiwum norbertanek w Imbramowicach, „Archiwa, Biblioteki i Muzea Kościelne”, t. 94, 2010.

${ }^{21}$ Z. Gluza, Archiwa Ośrodka KARTA, [w:] Archiwistyka społeczna, red. K. Ziętal, Warszawa, s. 27-35.

${ }^{22}$ E. Prałat, Ród historii, historia rodu. Archiwum kopaszewskie Chłapowskich, Leszno 2016.

${ }^{23}$ M. Niedźwiedzka, Zarys dziejów Filmoteki Narodowej, „Archiwa - Kancelarie Zbiory", nr 5 (7), 2014.

${ }^{24}$ Przykładowo: Otwarty skarbiec pamięci. Studia Zespołu Archiwum Państwowego w Opolu zebrane z okazji 60-lecia powstania instytucji, red. M. Lernart, cz. 1: Niezmienność idei i przemiany w cyklach czasu, Opole 2013; cz. 2: Bogactwo zasobu i przygoda poznania, Opole 2013; Archiwa i społeczeństwo. Pół wieku działalności Archiwum Państwowego w Koszalinie (1953) 1961-2011, red. J. Chojecka, Koszalin-Pruszcz Gdański 2011.

${ }^{25}$ Archiwum Państwowe we Wrocławiu 1811-2011. Przeszłość i wspótczesność, red. J. Drozd, J. Gołaszewski, Wrocław 2011.

${ }^{26}$ Przykładowo: K. Sobańska, Kształtowanie zasobu Archiwum Państwowego w Szczecinie w latach 1945-1955, „Szczeciński Informator Archiwalny”, t. 19, 2006, s. 43-68; B. Sobolowa, Udostępnianie zasobu Archiwum Głównego Akt Dawnych w latach 1945-1978, „Miscellanea Historico-Archivistica”, t. I, 1985, s. 73-85. 
„pomimo coraz dalej idącej naprzód informatyzacji współczesnego społeczeństwa informacyjnego, nadal istnieje potrzeba dokumentowania korzeni tego, na bazie czego powstają nowe struktury organizacyjne. [...] Także ze strony środowiska, szczególnie młodych adeptów archiwistyki słychać często głosy, sugerujące potrzebę poznania historii archiwów i ich zasobów, niejako w nowej odsłonie. Również wszystkich procesów, jakie zachodziły na przestrzeni dziejów w strukturach sieci archiwalnej i rzutujących na kształt i stan zgromadzonego zasobu."27

Świadectwem antropologizowania archiwoznawstwa są natomiast podejmowane badania nad personelem archiwów w przeszłości. Prym wiedzie w tym względzie Archiwum Państwowe w Katowicach, którego pracownicy na łamach czasopisma „Szkice Archiwalno- Historyczne” publikują artykuły dotyczące śląskich archiwistów ${ }^{28}$. Ponadto trzeba wymienić dwie publikacje poświęcone archiwistom Ryszardowi Mienickiemu ${ }^{29}$, Ryszardowi Przelaskowskiemu ${ }^{30}$ czy Józefowi Paczkowskiemu ${ }^{31}$. Ważne jest również wydawnictwo o archiwistach warszawskich $^{32}$.

27 T. Matuszak, O potrzebie prowadzenia badań archiwoznawczych uwag kilka, [w:] Toruńskie konfrontacje archiwalne, t. 2: Teoria archiwalna wczoraj, dziś, jutro, red. W. Chorążyczewski, A. Rosa, Toruń 2011, s. 321-336.

${ }_{28}$ S. Krupa, A. Staszków, Personel Staatsarchiv Kattowitz $w$ latach 1939-1945 w świetle ich akt osobowych, „Szkice Archiwalno-Historyczne”, t. 6, 2010; S. Krupa, Eustachy Czosnowski. Kierownik Archiwum Miejskiego w Bytomiu w latach 1945-1951, „Szkice Archiwalno-Historyczne”, t. 5, 2009; E. Matuszek, Stanisława Poprawska (1909-1985), „Szkice Archiwalno-Historyczne”, t. 5, 2009; J. Sowa, Halina Bolesławska (1954-1999), „Szkice Archiwalno-Historyczne”, t. 5, 2009; B. Kalinowska-Wójcik, Ezechiel Zivier-⿱亠乂yycie i działalności archiwisty i historyka na Górnym Śląsku na przełomie XIX i XX wieku, „Szkice Archiwalno-Historyczne”, t. 4, 2008; J. Szczepańczyk, Józefa Okoniewska - archiwistka Archiwum Książąt Pszczyńskich, „Szkice Archiwalno-Historyczne”, t. 4, 2008; T. Hajewski, M. Węcki, Dr Karl G. Bruchmann jako zwierzchnik niemieckiej stużby archiwalnej na Górnym Ślasku w latach 1939-1943, „Szkice Archiwalno-Historyczne”, t. 4, 2008; A. Machej, Wacław Bandura i Karol Bałon - pierwsi kierownicy cieszyńskiego archiwum, „Szkice Archiwalno-Historyczne”, t. 4, 2008.

${ }^{29}$ Ryszard Mienicki (1886-1956). Archiwista i historyk, red. W. Chorążyczewski, R. Degen, Toruń 2009.

30 W. Guzek, W. Chorążyczewski, J. Popłońska, Ryszard Przelaskowski. Dyrektor, bibliotekarz, archiwista, Warszawa 2010.

31 I. Mamczak-Gadkowska, Józef Paczkowski i jego wkład w budowę polskiej służby archiwalnej, Warszawa 1990.

${ }^{32}$ Wkład archiwistów warszawskich $w$ rozwój archiwistyki polskiej. Zbiór studiów poświęconych warszawskiemu środowisku archiwalnemu, red. A. Kulecka, Warszawa 2012. 
Przedmiotem refleksji mogą być w końcu również organizacja i współczesne funkcje archiwów np. archiwów zakładowych ${ }^{33}$, z powierzonym zasobem ${ }^{34}$, społecznych ${ }^{35}$. Osobno wymienić należy stosunkowo już dziś rzadkie publikacje poświęcone organizacji archiwów zagranicznych ${ }^{36}$.

W nurcie drugim odnoszącym się do zasobu archiwalnego można z kolei wyodrębnić dwa kierunki. Pierwszy obejmuje historię określonych zespołów lub zbiorów archiwalnych wraz z omówieniem ich zawartości. Nierzadko podnosi się tu aspekty metodyczne związane głównie z problematyką opracowania dokumentacji. Publikacje takie często zawierają również pierwiastek dyplomatyczny czy aktoznawczy (dzieje kancelarii) lub źródłoznawczy. Pokłosiem tego rodzaju badań są niezbyt częste w ostatnim czasie monografie zespołów lub zbiorów archiwalnych ${ }^{37}$ oraz znacznie bardziej powszechne drobne artykuły traktujące o dziejach i zawartości danego zespołu lub zbioru archiwalnego ${ }^{38}$.

${ }^{33}$ P. Wlezień, Archiwum Zakładowe Małopolskiego Urzędu Wojewódzkiego w Krakowie jako przykład archiwum zbiorczego na szczeblu wojewódzkim, [w:] Archiwa przejściowe i zbiorcze, Organizacja i funkcjonowanie, red. D. Drzewiecka, M. Jabłońska, Toruń 2016, s. 89-104.

${ }^{34}$ D. Kwiatkowski, Miejsce Archiwum PAN w strukturze Polskiej Akademii Nauk, „Poznański Rocznik Archiwalno-Historyczny", t. XII-XIV, 2005-2007, s. 45-50.

35 B. Kowal, Archiwum Południowo-Wschodniego Instytutu Narodowego w Przemyślu, [w:] Archiwa organizacji pozarządowych $w$ Polsce, red. T. Czarnota, M. Konstankiewicz, Warszawa-Lublin 2015, s. 89-106.

${ }^{36}$ Przykładowo: Z. Jaśkowska, Hiszpańska sieć archiwalna. Historia i organizacja, „Archiwista Polski”, nr 1, 2016, s. 7; W. Adamuszko, Organizacja archiwów na Białorusi, „Archeion”, t. 106, 2003, s. 191; A. Biedziak, Wtoska sieć archiwów państwowych, „Archiwista Polski”, 2008, nr 3, s. 51; A. Sobczak, Bundesarchiv - największa sieć archiwalna w Niemczech, „Archiwista Polski”, 2008, nr 3, s. 67; W. Sieliamieniew, Narodowe Archiwum Republiki Białoruś - wiodąca krajowa instytucja archiwalna, „Archiwista Polski”, 2006, nr 1, s. 9; J. Newman, Archiwa społeczne na Antypodach. Przekrojowy opis stanu dziedziny i problemów, które napotyka się w Nowej Zelandii, [w:] Archiwa społeczne. Modele wspótpracy z państwem, Warszawa 2015, s. 130-155, D.M. Groszek, Archiwa w Wielkiej Brytanii - organizacja i działalność, „Teki Archiwalne. Seria Nowa”, t. 10, 2009, s. 5-30; K. Klimiuk, Archiwa w Stanach Zjednoczonych Ameryki Pótnocnej - organizacja i działalność, „Teki Archiwalne. Seria Nowa”, t. 10, 2009, s. 31-46; W. Stępień, Archiwa państwowe na Słowacji: organizacja, działalność, zasoby, „Teki Archiwalne. Seria Nowa”, t. 10, 2009, s. 47-70.

${ }^{37}$ A. B. Małek, Kamera wojny $i$ domen Departamentu Białostockiego Nowych Prus Wschodnich 1796-1807. Monografia zespołu archiwalnego, Warszawa 2007; A. Barszcz, Prezydium Rady Ministrów i Urząd Rady Ministrów w latach 1945-1996 jako wytwórcy państwowego zasobu archiwalnego, Warszawa 2014.

38 Z. Jaśkowska, Spuścizna prof. Marii Paradowskiej w PAN Archiwum w Warszawie Oddział w Poznaniu, „Przegląd Archiwalno-Historyczny', t. 1, 2014; W. Bagieński, Akta Zarządu Miejskiego w Górze Kalwarii z 1945 r., „Archiwista Polski”, 2006, nr 1; P. Ję- 
Drugi kierunek reprezentują tzw. przeglądy archiwoznawcze, którym chciałbym poświęcić najwięcej uwagi. Można je rozumieć jako teksty naukowe stanowiące prezentację, usystematyzowanie, omówienie materiałów archiwalnych - źródeł historycznych dotyczących określonej problematyki, wytworzonych w określonym czasie i na danym obszarze, znajdujących się w zasobie konkretnego archiwum, archiwów lub innej/innych placówek wykonujących zadania archiwalne.

Przeglądy archiwoznawcze są zatem pokłosiem kwerendy tematycznej przeprowadzonej w określonym zespole/zbiorze archiwalnym lub wielu zespołach/ /zbiorach archiwalnych, w zasobie jednego lub kilku archiwów czy innych instytucji przechowujących archiwalia - bibliotek, muzeów, zarówno w kraju, jak i zagranicą.

Publikacje archiwoznawcze osadzone w omawianym nurcie można podzielić na kilka grup stosując różne kryteria. Ze względu na zakres kwerendy będą to przeglądy obejmujące:

- jeden zespół lub zbiór archiwalny ${ }^{39}$,

- określone grupy zespołów lub zbiorów archiwalnych (np. akta sądowe, spuścizny),

- cały zasób danego archiwum, zbiory danej biblioteki ${ }^{40}$ lub muzeum ${ }^{41}$,

- zasób kilku archiwów na określonym obszarze,

- zasób kilku archiwów oraz zbiory bibliotek i muzeów na określonym obszarze $^{42}$,

drzejewski, Akta Komisji Porządkowych Cywilno-Wojskowych (1790-1794), „Krakowski Rocznik Archiwalny", 2013, s. 129-157.

${ }^{39}$ W. Więch-Tchórzewska, Najcenniejsze materiaty archiwalne do dziejów Wschodniego Mazowsza i Południowego Podlasia w zespole akt Komisji Rządowej Spraw Wewnętrzych [w AGAD], [w:] Źródła do dziejów regionu. I Siedlecka Sesja Archiwalna, red. U. Głowacka-Maksymiuk, G. Welik, Siedlce 2002, s. 83-91; R. Sikorski, Materiaty archiwalne dotyczące Kościoła rzymskokatolickiego w okresie II Rzeczypospolitej w zespole: Akta Miasta Częstochowy (1759-1945), „Szkice Archiwalno-Historyczne”, nr 3, 2007, s. 113-122.

40 Z. Romaniuk, Źródła do początków obwodu białostockiego $w$ zbiorach Biblioteki Naukowej PAU i PAN w Krakowie, „Białostocczyzna”, r. 16, 2001, nr 1-2, s. 28-36.

${ }^{41}$ P. Jagieła, K. Sznotala, Materiały archiwalne Centralnego Muzeum Jeńców Wojennych $w$ Łambinowicach-Opolu dotyczące podchorażych Wojska Polskiego w niewoli niemieckiej, „Łambinowicki Rocznik Muzealny”, t. 33, 2010, s. 125-140.

${ }^{42}$ Archiwa, biblioteki, muzea. Źródła do dziejów Wielkopolski południowej, red. E. Andrysiak, Kalisz 2004; W. Gojniczek, A. Rusnok, Źródła do badań nad dziejami szkolnictwa na Śląsku Cieszyńskim w zbiorach Archiwum Państwowego w Katowicach Oddział w Cieszynie, Książnicy Cieszyńskiej oraz Biblioteki Tschammera, [w:] Książka, biblioteka, szkoła 
- zasób wszystkich archiwów w danym kraju,

- zasób wszystkich archiwów określonego typu lub danej sieci,

- zasób wszystkich archiwów oraz zbiory bibliotek i muzeów w danym kraju,

- zasób konkretnych archiwów, bibliotek i muzeów zagranicznych ${ }^{43}$,

- zasób wszystkich archiwów oraz zbiory bibliotek i muzeów.

Istotnym kryterium typologii przeglądów archiwoznawczych jest ich rzeczowa zawartość. Przedmiotem przeglądu archiwoznawczego mogą być archiwalia dotyczące danego regionu ${ }^{44}$, miasta ${ }^{45}, \mathrm{wsi}^{46}$, wydarzenia historycznego, procesu historycznego, określonego problemu, zagadnienia ${ }^{47}$ czy postaci historycznej ${ }^{48}$.

Przegląd archiwoznawczy może stanowić prezentację wszystkich archiwaliów z konkretnej epoki historycznej ${ }^{49}$ lub materiałów określonej prowenien-

w kulturze Śląska Cieszyńskiego. Materiały z konferencji naukowej, Cieszyn 4-5 listopada 1999, red. J. Spyra, Cieszyn 2001, s. 27-49.

${ }^{43}$ G. Ryżewski, Źródła do dziejów rodu Chreptowiczów i Grodzieńszczyzny z XV-XIX w. $w$ archiwach i bibliotekach polskich i zagranicznych (wschodnich), [w:] Pogranicze polsko-litewsko-białoruskie. Źródła historyczne, stan badań. Materiały z konferencji, red. M. Kietliński, Białystok 2003, s. 63-68.

${ }^{44}$ D. Magier, Źródła do dziejów regionu bialskopodlaskiego przechowywane i kształtowane przez Oddział AP w Radzyniu Podlaskim, [w:] Źródła do dziejów regionu. I Siedlecka Sesja Archiwalna, s. 63-75; G. Broda, Materiały archiwalne do dziejów ziemi kłodzkiej w AP we Wrocławiu i Oddziale Zamiejscowym w Kamieńcu Ząbkowickim, „Archeion”, t. 111, 2011, s. 291.

${ }^{45}$ M. Aleksiejuk, M. Rzepecka-Aleksiejuk, Kielecciana $w$ zasobie Archiwum Państwowego m. st. Warszawy, „Archeion”, t. 114, 2013, s. 221-232.

${ }^{46}$ M. Dalecki, Źródła do dziejów wsi Żurawica w zbiorach Archiwum Państwowego w Przemyślu, „Rocznik Historyczno-Archiwalny”, t. 20, 2007/2008, s. 133-139.

47 R. Stelmach, Źródła archiwalne do historii franciszkanów-obserwantów na Śląsku w Archiwum Państwowym we Wrocławiu, [w:] Bernardyni na Śląku w późnym średniowieczu, red. J. Kostowski, Wrocław 2005, s. 64-76; S. Krupa, Materiały do dziejów powstań śląskich w zasobie Archiwum Państwowego w Katowicach, „Szkice Archiwalno-Historyczne”, t. 8, 2011.

${ }^{48}$ B. Lesiak-Przybył, A. Warzecha, Materiaty archiwalne związane z osoba Heleny Modrzejewskiej przechowywane w Archiwum Państwowym w Krakowie. Przewodnik, Kraków 2009; A. Chachlowska, Materiaty związane ze Zbigniewem Herbertem w Archiwum Uniwersytetu Ekonomicznego w Krakowie, „Krakowski Rocznik Archiwalny”, t. 15, 2009, s. 199-205; J. Gaul, Akta dotyczące Józefa Piłsudskiego i Legionów Polskich w zespole Kancelarii Wojskowej Jego Wysokości Cesarza w Archiwum Wojny w Wiedniu, „Archeion', t. 114, 2013, s. 147.

${ }^{49}$ L. Wakuluk, Materiaty archiwalne dotyczace okupacji hitlerowskiej w zasobie archiwum inowrocławskiego - wartość badawcza, „Ziemia Kujawska”, t. 18, 2005, s. 163-170; 
$\mathrm{cji}^{50}$. Wyznacznikiem bywa też określony rodzaj dokumentacji np. fotograficzna, kartograficzna, techniczna itd. ${ }^{51}$

Omawiane prace archiwoznawcze można podzielić także ze względu sposób ich ogłaszania. Najmniej liczne są samodzielne zwarte przeglądy archiwoznawcze. W przeszłości inicjatorem tego typu wydawnictw była Naczelna Dyrekcja Archiwów Państwowych. Ich powstanie poprzedzała rozległa kwerenda w archiwach państwowych. Ostatnie takie publikacje ukazały się na początku XXI w. ${ }^{52}$

Przeglądy archiwoznawcze najczęściej ogłaszane są drukiem na łamach czasopism archiwistycznych, zarówno tych ogólnopolskich („Archeion”, „Archiwista Polski”, „Archiwa, Biblioteki i Muzea Kościelne”), jak i lokalnych. Omawiane prace można znaleźć także na kartach periodyków muzealnych ${ }^{53}$, rzadziej bibliotecznych ${ }^{54}$, oraz historycznych ogólnopolskich ${ }^{55}$ i lokalnych ${ }^{56}$.

Kolejną grupę stanowią przeglądy publikowane w opracowaniach zwartych poświęconych danemu zagadnieniu, postaci, wydarzeniu, regionowi itp., będące często pokłosiem konferencji naukowej ${ }^{57}$.

N. Kania, Archiwalia z okresu pierwszej wojny światowej dotyczace Gliwic w zasobie Archiwum Państwowego w Katowicach Oddział w Gliwicach, [w:] Wojna z Górnym Ślaskiem $w$ tle. Źródła, muzealia, projekty badawcze, red. D. Keller, S. Rosenbaum, Katowice 2017, s. $118-125$.

50 J. Łosowski, Staropolskie akta sądów szlacheckich i miejskich województw lubelskiego i betskiego oraz ziemi chetmińskiej w archiwach Moskwy i Jarosławia, „Archeion”, t. 107, 2004, s. 363.

${ }^{51}$ J. Sikorski, Materiały fotogrametryczne $w$ zasobie Archiwum Państwowego $w$ Gorzowie Wielkopolskim, „Archiwista Polski”, 2016, nr 3, s. 63.

${ }^{52}$ Źródta archiwalne do dziejów Żydów w Polsce, red. B. Woszczyński, V. Urbaniak, Warszawa 2001; Stan wojenny $w$ Polsce. Dokumenty i materiaty archiwalne 1981-1983, red. T, Walichnowski, Warszawa 2001; Między Sekwanq a Wisłą. Źródła do dziejów Francji i stosunków polsko-francuskich $w$ archiwach polskich, red. A. Laszuk, Warszawa 2002.

53 A. Sołtan, Źródła do dziejów Warszawy popowstaniowej w Rosyjskim Państwowym Archiwum Historycznym, „Almanach Muzealny”, t. 3, 2001, s. 177-186; A. Dziatczyk, Materiały archiwalne do powojennej historii Duszniki-Zdrój w zasobie Archiwum Państwowego we Wrocławiu Oddział w Kamieńcu Ząbkowickim, „Rocznik Muzeum Papiernictwa”, t. 9, 2015, s. 65-79.

54 T. Morawski, Materiaty archiwalne dotyczace Szkoty Podchorążych Sanitarnych przekazane w darze Głównej Bibliotece Lekarskiej, „Biuletyn Głównej Biblioteki Lekarskiej”, nr 362, 2000, s. 99-102.

${ }^{55}$ H. Mazur, Źródła do dziejów uzdrowisk w zasobie Archiwum Państwowego w Kielcach, „Kwartalnik Historii Kultury Materialnej”, r. 63, 2015, nr 3, s. 511-526.

${ }^{56}$ A. Bryk, Źródła do dziejów getta zduńskowolskiego w zasobie Archiwum Państwowego w Łodzi oraz jego Oddziału w Sieradzu, „Rocznik Łódzki”, t. 62, 2014, s. 161-176.

${ }^{57}$ M. Osiecka, Mosty na Wiśle $w$ Warszawie $w$ latach 1800-1914. Źródła archiwalne przechowywane w Archiwum Głównym Akt Dawnych, [w:] Mosty - dzieła sztuki i inżynierii, 
Jako osobliwe przedsięwzięcie należy wskazać cykl artykułów Ivo Łaborewicza „Źródła do dziejów polskiej archiwistyki” publikowanych na łamach „Archiwisty Polskiego". Są to poprzedzone komentarzem edycje źródeł dotyczących historii archiwów polskich ${ }^{58}$.

W archiwach państwowych od wielu dziesięcioleci archiwiści na zebraniach naukowych wygłaszają referaty poświęcone tematyce historycznej i archiwistyce. Obok metodyki archiwalnej tematem wystąpień jest także archiwoznawstwo. I tak np. w Archiwum Państwowym w Kielcach w latach 2007-2010 cztery referaty stanowiły przeglądy archiwoznawcze ${ }^{59}$. Referaty wygłaszane przez archiwistów na zebraniach naukowych w archiwach można znaleźć w postaci rękopisów lub maszynopisów w bibliotekach archiwów lub w zasobie historycznym, w zespołach stanowiących spuściznę kancelaryjną poszczególnych archiwów. Niektóre z referatów publikowane były w różnych periodykach, a niektóre przez pewien okres zamieszczano na stronie internetowej Naczelnej Dyrekcji Archiwów Państwowych ${ }^{60}$.

W typologii przeglądów archiwoznawczych można zaproponować podział ze względu na osobę autora. Będą to zatem prace przygotowane przez archiwistów, historyków lub inne grupy zawodowe, m.in. muzealników, bibliotekarzy.

Publikacje stanowiące przegląd źródeł archiwalnych dotyczących danej tematyki bardzo często zatytułowane są w następujący sposób: Źródła do dziejów...,

zabytki. Materiały sesji naukowej, Warszawa, 25-26 maja 2000 roku, red. B. Wierzbicka, Warszawa 2001, s. 58-70.

58 Przykładowo: I. Łaborewicz, Źródła do dziejów polskiej archiwistyki: organizacja Powiatowego Archiwum Państwowego w Zgorzelcu 1950 r., „Archiwista Polski”, 2013, nr 3, s. 25-29; tenże, Źródła do dziejów polskiej archiwistyki. Zakup archiwaliów przez Powiatowe Archiwum Państwowe w Legnicy - 1955 rok, „Archiwista Polski”, 2014, nr 3, s. 63-67; tenże, Źródła do dziejów polskiej archiwistyki. Poszukiwania kandydata na stanowisko kierownika Powiatowego Archiwum Państwowego w Wałbrzychu. 1951 rok, „Archiwista Polski”, 2014, nr 4, s. 11-18.

59 W 2007 r. P. Pawłowski wygłosił referat: „Materiały Solidarności. Region Ziemia Sandomierska w zasobie Sandomierskiego Stowarzyszenia „Pamięć i Solidarność”, w 2008 r. S. Solanin wygłosił referat: „Materiały do dziejów ochrony zdrowia i opieki społecznej z lat 1944-1975 w zasobie sandomierskiego archiwum”, a w latach 2009 i 2010 H. Mazur przygotował referaty: „Źródła do dziejów Chęcin w zasobie Archiwum Państwowego w Kielcach” i „Kielecciana kartograficzne i ikonograficzne z lat 1795-1866 w zasobie Archiwum Państwowego w Kielcach”; zob. H. Mazur, Działalność naukowa i wydawnicza Archiwum Państwowego w Kielcach w latach 1984-2011, „Świętokrzyskie Studia Archiwalno Historyczne", t. 1. 2012, s. 97-117.

${ }^{60}$ Referaty archiwistów, https://www.archiwa.gov.pl/pl/dla-uzytkownikow/wydawnictwa/e-publikacje/576-referaty-archiwist\%C3\%B3w (dostęp 08.03.2018). 
Źródła archiwalne dotyczace..., Materiaty archiwalne do historii... Warto jednak podkreślić, że nie wszystkie prace zawierające w tytułach wyżej wymienione sformułowania można uznać za opracowania archiwoznawcze. Bardzo podobnie tytułuje się również wybory i edycje źródeł dotyczących określonej tematyki ${ }^{11}$ oraz albumy i katalogi wystaw ${ }^{62}$.

Warto kilka słów poświęcić genezie powstawania przeglądów archiwoznawczych. Często są one pokłosiem opracowania zespołu archiwalnego. Dla archiwisty bazą wyjściową do przygotowania przeglądu może być opracowanie wstępu do inwentarza, zwłaszcza takich elementów jak dzieje aktotwórcy, dzieje zespołu i zawartość zespołu. Innym powodem mogą być prywatne zainteresowania naukowe archiwisty pobudzające go do poszukiwania źródeł dotyczących określonej tematyki, a następnie do sporządzenia przeglądu archiwoznawczego. Bodźcem mogą być w tym wypadku prace wykonywane na polu udostępniania - związane z udzielaniem informacji o zasobie, realizacją kwerend, obsługą klienta. Przegląd archiwalny może powstać także jako efekt wystawy, warsztatów, zajęć, czy innych przedsięwzięć popularyzatorskich i edukacyjnych. Odnalezione na ich potrzeby materiały z powodzeniem mogą stać się przedmiotem opracowania archiwoznawczego. Przegląd archiwoznawczy może być także efektem badań naukowych prowadzonych nad określonym zagadnieniem.

Powstanie przeglądu archiwoznawczego może być również celem samym w sobie. Takim przypadkiem będzie udział archiwisty w konferencji naukowej czy popularnonaukowej lub udział archiwisty w przygotowaniu publikacji zbiorowej poświęconej określonej tematyce. W przeszłości przeglądy archiwoznawcze stanowiły też efekt kwerend tematycznych zlecanych przez Naczelną Dyrekcję Archiwów Państwowych lub rejestracji archiwaliów prowadzonych przy okazji obchodów rozmaitych rocznic i jubileuszy. Nierzadko prace te miały charakter ideologiczno-propagandowy ${ }^{63}$.

Przeglądy archiwoznawcze różnią się między sobą układem omawianych archiwaliów. Niektóre prezentują materiały archiwalne w porządku rzeczowotematycznym. Edyta Łaborewicz w swym artykule poświęconym źródłom z za-

${ }^{61}$ Materiały źródłowe do dziejów Żydów w księgach grodzkich lubelskich z doby panowania Zygmunta III Wazy 1587-1632, oprac. H. Gmiterek, Lublin 2014; Źródła do dziejów ziemi lęborsko-bytowskiej. Od statusu lenna polskiego do inkorporacji do Królestwa Pruskiego i integracji z Pomorzem pruskim (1657-1815), tom 1 (1657-1740), tom 2 (1740-1815), wybór i opracowanie, B. Wachowiak, Z. Szultka, Warszawa 2011.

${ }^{62}$ B. Ratajewska, Materiały archiwalne do dziejów Wschowy, Warszawa-Leszno 2013.

${ }^{63}$ Np. S. Płaza, Źródła rękopiśmienne do dziejów wsi w Polsce feudalnej. Studium archiwoznawcze, Warszawa 1976. 
kresu hydrotechniki przechowywanym w Archiwum Państwowym we Wrocławiu Oddział w Legnicy zastosowała podział przeglądu najpierw na zespoły (Akta miasta Legnicy, Urząd Katastralny w Legnicy), a w obrębie każdego zespołu materiały archiwalne usystematyzowano według problematykiiobejmującej metody i sposoby wykorzystania zasobów wodnych ${ }^{64}$. Z kolei Andrzej Drakoniewicz swój przegląd materiałów archiwalnych dotyczących mniejszości narodowych i religijnych w Pabianicach oparł na układzie według zespołów archiwalnych ${ }^{65}$. Jeszcze inny porządek przyjął Hubert Mazur w artykule omawiającym źródła do dziejów Chęcin. Archiwalia usystematyzowano najpierw według epok historycznych, a następnie według zespołów archiwalnych ${ }^{66}$.

Istotną kwestią jest próba odpowiedzi na pytanie, czy badania archiwoznawcze są potrzebne i mają rację bytu w XXI w. Jeśli archiwistykę postrzegamy jako naukę, której przedmiotem są archiwa i archiwalia, to nie należy oczekiwać, że zerwie ona z refleksją nad historią i organizacją archiwów, czy dziejami i zawartością ich zasobów. Sytuacja tym bardziej nie może ulec zmianie, kiedy na archiwistykę spojrzymy szerzej, uznając, że jej przedmiotem jest dziedzina archiwalna, a więc „cały wycinek rzeczywistości, całe spektrum ludzkich postaw i działań (niekoniecznie w sformalizowanych ramach archiwum instytucjonalnego), w jakikolwiek sposób powiązanych z archiwaliami”'67.

Archiwoznawstwo to przede wszystkim dział archiwistyki, bez którego trudno wyobrazić sobie istnienie jej pozostałych działów - teorii i metodyki archiwalnej. Nie może być mowy o rozważaniach teoretycznych bez refleksji archiwoznawczej. Wszelkie uogólnienia, twierdzenia, terminy, pojęcia stosowane w dziedzinie archiwalnej muszą być wywiedzione z dziejów nie tylko archiwistyki, ale także archiwów. Współczesna metodyka archiwalna, od metodyki kształtowania zasobu, przez metodykę opracowania, na metodyce udostępniania kończąc, musi czerpać z dorobku minionych pokoleń archiwistów. Metodyka archiwalna nie

${ }^{64}$ E. Łaborewicz, Źródła z dziedziny hydrotechniki $w$ archiwaliach Legnicy sprzed 1945 r., „Archeion”, t. 99, 1998, s. 203-206.

65 A. Drakoniewicz, Materiały archiwalne przechowywane w Archiwum Państwowym $w$ Łodzi dotyczące mniejszości narodowych i religijnych $w$ Pabianicach, „Archeion” t. 116, 2015, s. 328-339.

${ }^{66}$ H. Mazur, Źródła do dziejów Chęcin w zasobie Archiwum Państwowego w Kielcach, „Między Wisłą a Pilicą”, t. 12, 2011, s. 165-200.

67 W. Chorążyczewski, Uwagi o przedmiocie i problematyce zantropologizowanej archiwistyki, [w:] Toruńskie konfrontacje archiwalne, t. 4: Nowa archiwistyka - archiwa $i$ archiwistyka w ponowoczesnym kontekście kulturowym, red. W. Chorążyczewski, W. Piasek, A. Rosa, Toruń 2014, s. 25-35. 
może odrywać się od wyników badań archiwoznawczych, zwłaszcza w aspekcie zadań archiwów ${ }^{68}$. Także paradygmat archiwoznawczy musi pozostawać z archiwoznawstwem w symbiozie. Jeśli archiwozofia jest „refleksją nad myślą archiwalną, miejscem archiwum i archiwistyki w dziejach, postrzeganiem historii archiwów, zbiorów i rozwiązań metodycznych poprzez osoby archiwistów”, jeśli jest działem zajmującym się „przeobrażeniami teorii i metodyki archiwalnej dokonującymi się w ślad za rozwojem archiwów, szukaniem jakiegoś sensu i kierunku tych przeobrażeń" ${ }^{69}$, to nie może być wątpliwości, że u jej podstaw musi znaleźć się klasycznie rozumiane archiwoznawstwo. Dla całej archiwistyki, czy szerzej dziedziny archiwalnej, archiwoznawstwo jest jednym z trzech filarów, wzajemnie się uzupełniającym i przenikającym z pozostałymi działami: teorią i metodyką archiwalną.

Pamiętać należy, że archiwistyka mimo prób wybijania się na niepodległość, jest nauką pomocniczą historii, bowiem „organizuje historykowi zasób źródeł, wprowadza do tego zasobu pewien ład, wyposaża historyka w narzędzia pozwalające wyszukiwać informacje o tym zasobie"70. Joachim Lelewel nazywał dzisiejsze nauki pomocnicze historii naukami dającymi poznawać źródła historyczne. Umożliwienie poznawania źródeł archiwalnych, to nie tylko ich gromadzenie, przechowywanie, zabezpieczanie, ewidencja, opracowanie i udostępnianie, ale także dostarczenie podstawowych informacji na ich temat. Wiadomości te powinny dotyczyć dziejów aktotwórcy, dziejów zespołu archiwalnego i jego zawartości. Oczywiście w pierwszej kolejności potrzeby informacyjne powinny zaspokajać pomoce archiwalne, w szczególności inwentarze, indeksy, sumariusze, katalogi, a także przewodniki i informatory o zasobie. W dalszej perspektywie taką rolę spełniać mogą właśnie przeglądy archiwoznawcze, pomyślane jako przewodniki po źródłach dotyczących danej tematyki w określonym zespole, zasobie jednego czy kilku archiwów lub innych instytucji wykonujących zadania archiwalne.

W takiej postaci przeglądy archiwoznawcze są i mogą być dalej cennym wsparciem dla korzystających z pracowni naukowych/czytelni archiwów państwowych, zwłaszcza historyków i genealogów. To nieocenione źródło wiedzy także dla samych archiwistów w realizacji zadań na niwie udostępniania, związanych głównie z udzielaniem informacji o zasobie czy prowadzeniem

${ }^{68}$ W. Kwiatkowska, Dorobek polskiej archiwistyki $w$ zakresie metodyki opracowania zasobu archiwalnego, Warszawa 2014, s. 249-268.

69 D. Magier, Czas archiwozofii, [w:] Toruńskie konfrontacje archiwalne, t. 2.

70 W. Chorążyczewski, Archiwistyka dla początkujących, s. 3. 
poszukiwań. Każdy przegląd archiwoznawczy może być punktem wyjścia dla organizacji inicjatyw edukacyjnych i popularyzatorskich np. wystaw. Mogą być one podstawą także do przygotowania prac naukowych czy edycji źródeł. Pomoce tego typu szczególnie przydatne mogą być archiwistom początkującym. Archiwoznawstwo jest więc działem archiwistyki przydatnym w bieżącej pracy archiwów.

W dobie tzw. retrokonwersji, której celem jest udostępnienie wszystkich inwentarzy zespołów i zbiorów archiwalnych w sieci, badania archiwoznawcze w odniesieniu do zawartości i dziejów zespołów mogą być kwestionowane. Rodzi się pytanie, czemu archiwiści mieliby poświęcać czas na przygotowanie przeglądów archiwoznawczych, skoro wszystkie inwentarze, a z czasem także zdigitalizowane jednostki archiwalne można będzie znaleźć w sieci, na portalu „Szukajwarchiwach.pl”. W pierwszej kolejności trzeba zauważyć, że zasób archiwalny w odróżnieniu od np. zbiorów bibliotecznych ma charakter nie tematyczny, a strukturalny. Efektem tego jest rozproszenie materiałów archiwalnych dotyczących danej tematyki w różnych zespołach i zbiorach archiwalnych, co jest dla użytkowników sporą trudnością, pomimo wciąż doskonalonych narzędzi wyszukiwawczych. Przestrzeganie zasady pertynencji terytorialnej przy burzliwych dziejach Polski, pociągających za sobą częste i radykalne zmiany granic oraz równie częste podziały administracyjne, przesądza o trudnym do uchwycenia rozmieszczeniu zasobu archiwalnego w różnych archiwach. Zadaniem więc przeglądów archiwoznawczych winno być wyjaśnienie przyczyny rozproszenia archiwaliów do danego zagadnienia nie tylko w różnych zespołach i zbiorach archiwalnych, ale także różnych archiwach czy nawet zbiorach innych instytucji z bibliotekami i muzeami na czele, nie tylko w Polsce, ale i zagranicą. Przegląd źródeł nierozerwalnie musi wiązać się z dziejami ich twórcy, obszarem i chronologią ich działania, a zwłaszcza kompetencjami, które determinowały produkcję kancelaryjną. Inwentarze zespołów i zbiorów archiwalnych bez względu na postać cechuje fakt, że dostarczają one informacji o faktycznym stanie archiwaliów. Natomiast we wstępach znaleźć można wiadomości o dziejach zespołów i zbiorów, przy czym najbardziej interesujące będą dane o poniesionych stratach w dokumentacji w wyniku wojen i klęsk żywiołowych, a także dane o dokonanym brakowaniu. Przeglądy archiwoznawcze powinny zatem także informować o bezpowrotnie utraconej z różnych powodów dokumentacji, a jeśli jest to możliwe wskazywać alternatywę w postaci innych źródeł. Archiwa powinny nie tylko informować o zgromadzonych materiałach archiwalnych, ale także o dokumentacji, której nie znajdziemy na archiwalnych półkach z podaniem przyczyn tego stanu rzeczy. 
Kolejną kwestią jest opis jednostki archiwalnej, którego głębia informacyjna zawsze będzie ograniczona. Innymi słowy, nie ma możliwości wiernego i pełnego oddania zawartości jednostki archiwalnej w jej opisie, zwłaszcza w przypadku obszernych i zróżnicowanych treściowo jednostek. Warto ponadto dodać, że w historiografii otwierają się stale nowe kierunki i obszary badawcze. Opisy jednostek archiwalnych nie zawsze będą tak skonstruowane, aby odpowiadać owym potrzebom. I w tym wypadku pomocne mogą okazać się przeglądy archiwoznawcze. Archiwiści zajmujący się archiwoznawstwem powinni mieć duże rozeznanie w zmianach w łonie historiografii i podążać za nowymi kierunkami badań. Nowe kierunki badań archiwoznawczych muszą zatem być skorelowane z badaniami w zakresie innych działów archiwistyki oraz z nowymi nurtami badań historycznych.

Zasygnalizowania wymaga fakt, że badania archiwoznawcze osadzone są w podstawach prawnych działalności archiwów, przede wszystkim w ustawie. Obliguje ona archiwa do prowadzenia prac naukowych oraz wydawniczych w dziedzinie archiwistyki i nauk pokrewnych oraz prowadzenie działalności informacyjnej ${ }^{71}$. Statuty poszczególnych archiwów państwowych stwierdzają, że wśród ich zadań w zakresie prowadzenia działalności naukowej i wydawniczej jest: „prowadzenie badań indywidualnych i zespołowych z zakresu archiwistyki i dziedzin pokrewnych". Z kolei w zakres działalności informacyjnej wpisuje się: „przygotowywanie informatorów o materiałach archiwalnych i Archiwum” oraz wyszukiwanie i upowszechnianie informacji o zawartości zasobu Archiwum, w szczególności w ramach kwerend tematycznych"72. Przeglądy archiwoznawcze są zatem publikacjami będącymi efektem prac usytuowanych na styku działalności naukowej i informacyjnej.

Prace o charakterze przeglądów archiwoznawczych cechuje znaczne rozproszenie jeśli chodzi miejsce ich publikowania. Jak już wyżej wspomniano są one publikowane nie tylko na łamach czasopism ogólnopolskich, ale także na kartach periodyków regionalnych i lokalnych, czasem także pism specjali-

${ }^{71}$ Ustawa z dnia 14 lipca 1983 r. o narodowym zasobie archiwalnym i archiwach, Dz.U. z 2008 r., poz. 217, 357.

72 Zob. m.in. Statut Archiwum Państwowego w Bydgoszczy stanowiący Załącznik do Decyzji Nr 28 Naczelnego Dyrektora Archiwów Państwowych z dnia 30 grudnia 2009 r. w sprawie nadania statutu Archiwum Państwowemu w Bydgoszczy ze zmianami wprowadzonymi Decyzją Nr 31 Naczelnego Dyrektora Archiwów Państwowych z dnia 18 września 2013 r. oraz Decyzją nr 7 Naczelnego Dyrektora Archiwów Państwowych z dnia 30 stycznia 2014 r.; http://www.bip.ap.gov.pl/dokument.php?iddok=639\&idm$\mathrm{p}=840 \& \mathrm{r}=\mathrm{o}$ (dostęp:08.03.2018). 
stycznych. Stąd na ogół są to wydawnictwa słabo rozpowszechnione, trudno dostępne, a czasem wręcz nieznane. Rozwiązaniem tego problemu mógłby być powrót do opracowywania bibliografii archiwistyki polskiej.

Badania archiwoznawcze nie mają spójnego charakteru. Po pierwsze oznacza to, że publikacje stanowiące przegląd źródeł do danej tematyki powstają z inicjatywy konkretnych osób - archiwistów, historyków, muzealników (z racji ich osobistych zainteresowań, prowadzonych prac naukowych, działań na polu opracowania czy udostępniania zasobu), rzadziej instytucji - archiwów, uczelni wyższych, muzeów, bibliotek (z racji podejmowanych badań naukowych czy realizowanych kwerend). Te indywidualne, jednostkowe, często odosobnione badania prowadzone są w izolacji od badań realizowanych przez innych badaczy lub w innych ośrodkach. Brak spójności w tematyce przeglądów archiwoznawczych występuje także w badaniach prowadzonych przez konkretną osobę. Najbardziej planowo, systematycznie i kompleksowo prezentuje się rejestracja poloników prowadzona przez Romana Stelmacha i Jerzego Gaula. Nie rezygnując z oddolnych inicjatyw archiwoznawczych, właściwym krokiem byłby powrót do inicjowania i koordynowania badań archiwoznawczych przez np. Naczelną Dyrekcję Archiwów Państwowych. Pozwoliłoby to na kompleksowe i systematyczne zorganizowanie refleksji i dociekań na niwie archiwoznawstwa.

Odrodzeniu archiwoznawstwa mogłoby służyć ożywienie aktywności naukowej i wydawniczej archiwów państwowych w ogóle oraz wsparcie dla tych archiwistów, którzy chcieliby badania naukowe (także archiwoznawcze) realizować.

Wspomniano już wcześniej, że część referatów wygłaszanych przez archiwistów na zebraniach naukowych nie doczekała się nigdy druku. Może warto byłoby zainicjować akcję digitalizacji tego typu materiałów i ich publikacji w sieci po uregulowaniu kwestii związanych z prawami autorskimi.

Bardzo dobrym rozwiązaniem byłoby także, aby portal „szukajwarchiwach. pl" dostarczał nie tylko informacje o pomocach archiwalnych do danego zespołu lub zbioru archiwalnego, ale wskazywał też literaturę przedmiotu. Byłyby to monografie zespołów lub zbiorów archiwalnych, przeglądy archiwoznawcze $\mathrm{i}$ inne podobne.

\section{Bibliografia}

Adamuszko, Władimir. „Organizacja archiwów na Białorusi.” Archeion 106 (2003): 191-206.

Aleksiejuk, Maciej, Marta Rzepecka-Aleksiejuk. „Kielecciana w zasobie Archiwum Państwowego m.st. Warszawy.” Archeion 114 (2013): 221-232. 
Andrysiak, Ewa, red. Archiwa, biblioteki, muzea. Źródła do dziejów Wielkopolski południowej. Kalisz: KTPN, 2004.

Bachulski, Aleksy, Kazimierz Konarski, Adam Wolf. Polski słownik archiwalny. Warszawa: Naczelna Dyrekcja Archiwów Państwowych, 1952.

Bagieński, Włodzimierz. „Akta Zarządu Miejskiego w Górze Kalwarii z 1945 r.” Archiwista Polski 11, nr 1 (2006): 65-73.

Barszcz, Anna. Prezydium Rady Ministrów i Urząd Rady Ministrów w latach 1945-1996 jako wytwórcy państwowego zasobu archiwalnego. Warszawa: Naczelna Dyrekcja Archiwów Państwowych, 2014.

Biedziak, Agata. „Włoska sieć archiwów państwowych.” Archiwista Polski 13, nr 3 (2008): 51-66.

Biernat, Czesław. Problemy archiwistyki wspótczesnej. Warszawa: Państwowe Wydawnictwa Naukowe, 1977.

Broda, Grażyna. „Materiały archiwalne do dziejów ziemi kłodzkiej w AP we Wrocławiu i Oddziale Zamiejscowym w Kamieńcu Ząbkowickim.” Archeion 111 (2011): 291-301.

Bryk, Adrianna. „Źródła do dziejów getta zduńskowolskiego w zasobie Archiwum Państwowego w Łodzi oraz jego Oddziału w Sieradzu.” Rocznik Łódzki 62 (2014): 161-176.

Chachlowska, Aneta. „Materiały związane ze Zbigniewem Herbertem w Archiwum Uniwersytetu Ekonomicznego w Krakowie." Krakowski Rocznik Archiwalny 15 (2009): 209-218.

Chojecka, Lidia, red. Archiwa i społeczeństwo: pót wieku działalności Archiwum Państwowego w Koszalinie (1953) 1961-2011: materiaty. Koszalin; Pruszcz Gdański: Archiwum Państwowe w Koszalinie [etc.], 2011.

Chorążyczewski, Waldemar. Archiwistyka dla początkujących. Toruń, 2014. https:// repozytorium.umk.pl/bitstream/handle/item/2191/Archiwistyka_dla_poczatkujacych_wersja_1.pdf?sequence $=1$.

Chorążyczewski, Waldemar. „Uwagi o przedmiocie i problematyce zantropologizowanej archiwistyki." W Toruńskie konfrontacje archiwalne, t. 4: Nowa archiwistyka - archiwa $i$ archiwistyka $w$ ponowoczesnym kontekście kulturowym, red. Waldemar Chorążyczewski, Wojciech Piasek, Agnieszka Rosa, 25-35. Toruń: Wydawnictwo Naukowe Uniwersytetu Mikołaja Kopernika, 2014.

Chorążyczewski, Waldemar, Robert Degen, red. Ryszard Mienicki (1886-1956): archiwista i historyk. Toruń, Wydawnictwo Naukowe Uniwersytetu Mikołaja Kopernika, 2009.

Ciara, Stefan. Archiwa a uniwersytety $w$ Krakowie i Lwowie $w$ latach 1877/78-1918, Warszawa: NDAP - Wydział Wydawnictw, 2002.

Dalecki, Maciej. „Źródła do dziejów wsi Żurawica w zbiorach Archiwum Państwowego w Przemyślu." Rocznik Historyczno-Archiwalny 20 (2007-2008): 133-139.

Dębowska, Maria. „Archiwum norbertanek w Imbramowicach.”, Archiwa, Biblioteki i Muzea Kościelne 94 (2010): 29-38.

Drakoniewicz, Andrzej. „Materiały archiwalne przechowywane w Archiwum Państwowym w Łodzi dotyczące mniejszości narodowych i religijnych w Pabianicach." Archeion 116 (2015): 328-339. 
Dziatczyk, Anna. „Materiały archiwalne do powojennej historii Duszniki-Zdrój w zasobie Archiwum Państwowego we Wrocławiu Oddział w Kamieńcu Ząbkowickim." Rocznik Muzeum Papiernictwa 9 (2015): 65-79.

Gaul, Jerzy. „Akta dotyczące Józefa Piłsudskiego i Legionów Polskich w zespole Kancelarii Wojskowej Jego Wysokości Cesarza w Archiwum Wojny w Wiedniu." Archeion 114 (2013): 147-156.

Gluza, Zbigniew. „Archiwa Ośrodka KARTA.” W Archiwistyka społeczna, red. Katarzyna Ziętal, 27-35. Warszawa.

Gmiterek, Henryk, oprac. Materiały źródłowe do dziejów Żydów w księgach grodzkich lubelskich z doby panowania Zygmunta III Wazy 1587-1632. Lublin: Archiwum Państwowe; Wydawnictwo Uniwersytetu Marii Curie-Skłodowskiej, 2014.

Gojniczek, Wacław, Anna Rusnok. „Źródła do badań nad dziejami szkolnictwa na Śląsku Cieszyńskim w zbiorach Archiwum Państwowego w Katowicach Oddział w Cieszynie, Książnicy Cieszyńskiej oraz Biblioteki Tschammera.” W Książka, biblioteka, szkoła w kulturze Śląska Cieszyńskiego: materiały z konferencji naukowej, Cieszyn 4-5 listopada 1999, red. Janusz Spyra, 27-49.Cieszyn: Książnica Cieszyńska, 2001.

Groszek, Daniel Marcin. „Archiwa w Wielkiej Brytanii - organizacja i działalność.” Teki Archiwalne. Seria Nowa 10 (2009): 5-30.

Guzek, Wioletta, Waldemar Chorążyczewski, Joanna Popłońska. Ryszard Przelaskowski. Dyrektor, bibliotekarz, archiwista. Warszawa: Biblioteka Publiczna m. st. Warszawy Biblioteka Główna Województwa Mazowieckiego, 2010.

Hajewski, Tomasz, Mirosław Węcki. „Dr Karl G. Bruchmann jako zwierzchnik niemieckiej służby archiwalnej na Górnym Śląsku w latach 1939-1943.”, Szkice Archiwalno-Historyczne 4 (2008): 75-95.

Hlebionek, Marcin. „Archiwum parafialne w Gietrzwałdzie do 1890 roku.”, Archiwista Polski 6, nr 1 (2001): 68-85.

Jagieła, Przemysław, Krzysztof Sznotala. „Materiały archiwalne Centralnego Muzeum Jeńców Wojennych w Łambinowicach-Opolu dotyczące podchorążych Wojska Polskiego w niewoli niemieckiej." Łambinowicki Rocznik Muzealny 33 (2010): 125-140.

Jaśkowska, Zuzanna. „Hiszpańska sieć archiwalna. Historia i organizacja.” Archiwista Polski 21, nr 1 (2016): 7-15.

Jaśkowska, Zuzanna. „Spuścizna prof. Marii Paradowskiej w PAN Archiwum w Warszawie Oddział w Poznaniu." Przegląd Archiwalno-Historyczny 1 (2014): 21-28.

Jędrzejewski, Przemysław. „Akta Komisji Porządkowych Cywilno-Wojskowych (1790-1794)". Krakowski Rocznik Archiwalny 13 (2013): 129-157.

Kalinowska-Wójcik, Barbara. „Ezechiel Zivier - życie i działalności archiwisty i historyka na Górnym Śląsku na przełomie XIX i XX wieku.", Szkice Archiwalno-Historyczne 4 (2008): 37-47.

Kania, Natalia. „Archiwalia z okresu pierwszej wojny światowej dotyczące Gliwic w zasobie Archiwum Państwowego w Katowicach Oddział w Gliwicach." W Wojna z Górnym Śląskiem $w$ tle: źródła, muzealia, projekty badawcze, red. Dawid Keller, Sebastian Rosenbaum, 118-125. Katowice; Warszawa: Instytut Pamięci Narodowej - Komisja Ścigania Zbrodni przeciwko Narodowi Polskiemu, 2017. 
Klimiuk, Kamil. „Archiwa w Stanach Zjednoczonych Ameryki Północnej - organizacja i działalność." Teki Archiwalne. Seria Nowa 10 (2009): 31-46.

Kołodziej, Edward. Zarys dziejów Archiwum Akt Nowych w latach 1919-2008. Warszawa: Archiwum Akt Nowych, 2008.

Kowal, Bogumiła. „Archiwum Południowo-Wschodniego Instytutu Narodowego w Przemyślu." W Archiwa organizacji pozarządowych w Polsce, red. Tomasz Czarnota, Marek Konstankiewicz, 89-106. Warszawa: Naczelna Dyrekcja Archiwów Państwowych; Lublin: Wydawnictwo Uniwersytetu Marii Curie-Skłodowskiej, 2015.

Krochmal, Anna. Archiwum historyczne eparchii przemyskiej. Warszawa: Naczelna Dyrekcja Archiwów Państwowych; Przemyśl: Archiwum Państwowe, 2016.

Krupa, Sławomira. „Eustachy Czosnowski. Kierownik Archiwum Miejskiego w Bytomiu w latach 1945-1951." Szkice Archiwalno-Historyczne 5 (2009): 141-151.

Krupa, Sławomira. „Materiały do dziejów powstań śląskich w zasobie Archiwum Państwowego w Katowicach." Szkice Archiwalno-Historyczne 8 (2011): 197-221.

Krupa, Sławomira, Antonina Staszków. „Personel Staatsarchiv Kattowitz w latach 1939-1945 w świetle ich akt osobowych.” Szkice Archiwalno-Historyczne 6 (2010): 101-116.

Kulecka, Alicja, red. Wkład archiwistów warszawskich $w$ rozwój archiwistyki polskiej: zbiór studiów poświęconych warszawskiemu środowisku archiwalnemu. Warszawa: Wydawnictwa Uniwersytetu Warszawskiego, 2012.

Kwiatkowska, Wiesława. Dorobek polskiej archiwistyki $w$ zakresie metodyki opracowania zasobu archiwalnego. Warszawa: Naczelna Dyrekcja Archiwów Państwowych. Departament Organizacji i Udostępniania. Wydział Popularyzacji i Wydawnictw, 2014.

Kwiatkowski, Dariusz. „Miejsce Archiwum PAN w strukturze Polskiej Akademii Nauk.” Poznański Rocznik Archiwalno-Historyczny 12-14 (2005-2007): 45-50.

Laszuk, Anna, red. Między Sekwaną a Wisłą. Źródła do dziejów Francji i stosunków polsko-francuskich $w$ archiwach polskich. Warszawa: Naczelna Dyrekcja Archiwów Państwowych; „ASPRA-JR”, 2002.

Lenart, Mirosław, red. Otwarty skarbiec pamięci. Studia Zespołu Archiwum Państwowego w Opolu zebrane z okazji 60-lecia powstania instytucji, cz. 1-2. Opole: Archiwum Państwowe; Warszawa: Naczelna Dyrekcja Archiwów Państwowych, 2013.

Lesiak-Przybył, Bożena, Aldona Warzecha. Materiaty archiwalne związane z osoba Heleny Modrzejewskiej przechowywane $w$ Archiwum Państwowym $w$ Krakowie: przewodnik. Kraków: Archiwum Państwowe, 2009.

Łaborewicz, Edyta. „Źródła z dziedziny hydrotechniki w archiwaliach Legnicy sprzed 1945 r." Archeion 99 (1998): 203-206.

Łaborewicz Iwo. „Źródła do dziejów polskiej archiwistyki. Organizacja Powiatowego Archiwum Państwowego w Zgorzelcu 1950 r." Archiwista Polski 18, nr 3 (2013): 25-29.

Łaborewicz Iwo. „Źródła do dziejów polskiej archiwistyki. Zakup archiwaliów przez Powiatowe Archiwum Państwowe w Legnicy - 1955 rok." Archiwista Polski 19, nr 3 (2014): 63-67.

Łaborewicz Iwo. „Źródła do dziejów polskiej archiwistyki. Poszukiwania kandydata na stanowisko kierownika Powiatowego Archiwum Państwowego w Wałbrzychu. 1951 rok.", Archiwista Polski 19, nr 4 (2014): 11-18. 
Łosowski, Janusz. „Staropolskie akta sądów szlacheckich i miejskich województw lubelskiego i bełskiego oraz ziemi chełmskiej w archiwach Moskwy i Jarosławia.", Archeion 107 (2004): 363-373.

Machej, Anna. „Wacław Bandura i Karol Bałon - pierwsi kierownicy cieszyńskiego archiwum." Szkice Archiwalno-Historyczne 4 (2008): 96-98.

Maciejewska, Wanda, red. Polski słownik archiwalny. Warszawa; Łódź: Państwowe Wydawnictwo Naukowe. Oddział, 1974.

Magier, Dariusz. „Czas archiwozofii.” W Toruńskie konfrontacje archiwalne, t. 2: Teoria archiwalna - wczoraj - dziś - jutro, red. Waldemar Chorążyczewski, Agnieszka Rosa, 9-20. Toruń: Wydawnictwo Naukowe Uniwersytetu Mikołaja Kopernika, 2011.

Magier, Dariusz. „Źródła do dziejów regionu bialskopodlaskiego przechowywane i kształtowane przez Oddział AP w Radzyniu Podlaskim.” W Źródła do dziejów regionu: I Siedlecka Sesja Archiwalna, red. Urszula Głowacka-Maksymiuk, Grzegorz Welik, 63-75. Siedlce: FRBR „Sigillum”; AP, 2002.

Majewski, Piotr. Wojna i kultura. Instytucje kultury polskiej w okupacyjnych realiach Generalnego Gubernatorstwa 1939-1945. Warszawa: Wydawnictwo Trio, 2005.

Małek, Ariusz B. Kamera wojny i domen Departamentu Białostockiego Nowych Prus Wschodnich 1796-1807: monografia zespołu archiwalnego. Warszawa: Naczelna Dyrekcja Archiwów Państwowych. Wydział Wydawnictw, 2007.

Mamczak-Gadkowska, Irena. Archiwa państwowe II Rzeczpospolitej. Poznań: Wydawnictwo Naukowe Uniwersytetu im. Adama Mickiewicza, 2006.

Mamczak-Gadkowska, Irena. Józef Paczkowski i jego wkład w budowę polskiej służby archiwalnej. Warszawa; Łódź: Państwowe Wydawnictwo Naukowe, 1990.

Matuszak, Tomasz. Archiwum Państwowe w Piotrkowie Trybunalskim 1919-1951. Piotrków Trybunalski; Radzyń Podlaski: Radzyńskie Stowarzyszenie Inicjatyw Lokalnych [etc.], 2009.

Matuszak, Tomasz. „O potrzebie prowadzenia badań archiwoznawczych uwag kilka.” W Toruńskie konfrontacje archiwalne, t. 2: Teoria archiwalna - wczoraj-dziś - jutro, red. Waldemar Chorążyczewski, Agnieszka Rosa, 321-336. Toruń: Wydawnictwo Naukowe Uniwersytetu Mikołaja Kopernika, 2011.

Matuszek, Elżbieta. „Stanisława Poprawska (1909-1985).” Szkice Archiwalno-Historyczne 5 (2009): 153-156.

Mazur, Hubert. „Działalność naukowa i wydawnicza Archiwum Państwowego w Kielcach w latach 1984-2011." Świętokrzyskie Studia Archiwalno Historyczne 1 (2012): 65-96.

Mazur, Hubert. „Źródła do dziejów Chęcin w zasobie Archiwum Państwowego w Kielcach." Między Wistą a Pilica 12 (2011): 165-200.

Mazur, Hubert. „Źródła do dziejów uzdrowisk w zasobie Archiwum Państwowego w Kielcach.” Kwartalnik Historii Kultury Materialnej 63, nr 3 (2015): 511-526.

Morawski, Tomasz. „Materiały archiwalne dotyczące Szkoły Podchorążych Sanitarnych przekazane w darze Głównej Bibliotece Lekarskiej.” Biuletyn Głównej Biblioteki Lekarskiej 362 (2000): 99-102.

Nabożny, Marcin. „Archiwum Diecezjalne w Rzeszowie. Powstanie, zasób i działalność.” Archiwa, Biblioteki i Muzea Kościelne 97 (2012): 139-207. 
Newman, Joanna. „Archiwa społeczne na Antypodach. Przekrojowy opis stanu dziedziny i problemów, które napotyka się w Nowej Zelandii." W Archiwa społeczne. Modele wspótpracy z państwem, red. Katarzyna Ziętal, 130-143.Warszawa: Ośrodek KARTA, 2015.

Niedźwiedzka, Magdalena. „Zarys dziejów Filmoteki Narodowej.” Archiwa - Kancelarie Zbiory 5(7) (2014): 93-109.

Niestrój, Henryk. „Wynagrodzenie, a praca naukowa w archiwum”. Dostęp 28.01.2018. http://rotulus.arcaion.pl/archiwistyka/wynagrodzenie-a-praca-naukowa-w-archiwum/.

Osiecka, Małorzata. „Mosty na Wiśle w Warszawie w latach 1800-1914. Źródła archiwalne przechowywane w Archiwum Głównym Akt Dawnych." W Mosty - dzieła sztuki i inżynierii, zabytki: materiały sesji naukowej, Warszawa, 25-26 maja 2000 roku, red. Bożena Wierzbicka, 71-86. Warszawa: Towarzystwo Opieki nad Zabytkami, 2001.

Płaza, Stanisław. Źródła rękopiśmienne do dziejów wsi w Polsce feudalnej. Studium archiwoznawcze. Warszawa: Państwowe Wydawnictwo Naukowe, 1976.

Prałat, Emilian. Ród historii, historia rodu: archiwum kopaszewskie Chłapowskich. Leszno: Archiwum Państwowe; Łódź: Księży Młyn Dom Wydawniczy Michał Koliński; [Warszawa]: Naczelna Dyrekcja Archiwów Państwowych, 2016.

Ratajewska, Barbara. Materiaty archiwalne do dziejów Wschowy. Leszno: Archiwum Państwowe; [Warszawa: Naczelna Dyrekcja Archiwów Państwowych], 2013.

Robótka, Halina. Wprowadzenie do archiwistyki. Toruń: Wydawnictwo Uniwersytetu Mikołaja Kopernika, 2002.

Robótka, Halina, Bohdan Ryszewski, Andrzej Tomczak. Archiwistyka. Warszawa: Państwowe Wydawnictwo Naukowe, 1989.

Roman, Wanda Krystyna. Centralne Archiwum Wojskowe 1918-1998: tradycje, historia, wspótczesność służby archiwalnej Wojska Polskiego. Toruń: Wydawnictwo Adam Marszałek, 2002.

Romaniuk, Zbigniew. „Źródła do początków obwodu białostockiego w zbiorach Biblioteki Naukowej PAU i PAN w Krakowie." Białostocczyzna 1-2 (2001): 28-36.

Ryszewski, Bohdan. Archiwistyka: przedmiot, zakres, podziat: studia nad problemem. Poznań: Państwowe Wydawnictwo Naukowe, 1972.

Ryżewski Grzegorz. „Źródła do dziejów rodu Chreptowiczów i Grodzieńszczyzny z XV-XIX w. w archiwach i bibliotekach polskich i zagranicznych (wschodnich)." W Pogranicze polsko-litewsko-białoruskie: źródła historyczne, stan badań: materiały z konferencji, red. Marek Kietliński, 63-68. Białystok: „Prymat”, 2003.

Sieliamieniew, Wiaczesław. „Narodowe Archiwum Republiki Białoruś - wiodąca krajowa instytucja archiwalna." Archiwista Polski 11, nr 1 (2006): 9-14.

Sikorski, Juliusz. „Materiały fotogrametryczne w zasobie Archiwum Państwowego w Gorzowie Wielkopolskim.” Archiwista Polski 21, nr 3 (2016): 63-74.

Sikorski, Robert. „Materiały archiwalne dotyczące Kościoła rzymskokatolickiego w okresie II Rzeczypospolitej w zespole: Akta Miasta Częstochowy (1759-1945)." Szkice Archiwalno-Historyczne 3 (2007): 113-122.

Skrzyński, Tomasz. „Archiwum Nauki Polskiej Akademii Nauk i Polskiej Akademii Umiejętności: z przeszłości i teraźniejszości.” Archiwista Polski 9, nr 1 (2004): 17-23. 
Sobańska, Karolina. „Kształtowanie zasobu Archiwum Państwowego w Szczecinie w latach 1945-1955." Szczeciński Informator Archiwalny 19 (2006): 43-68.

Sobczak, Anna. „Bundesarchiv - największa sieć archiwalna w Niemczech.” Archiwista Polski 13, nr 3 (2008): 67-76.

Sobolowa, Barbara. „Udostępnianie zasobu Archiwum Głównego Akt Dawnych w latach 1945-1978." Miscellanea Historico-Archivistica 1 (1985): 73-86.

Sołtan, Andrzej. „Źródła do dziejów Warszawy popowstaniowej w Rosyjskim Państwowym Archiwum Historycznym." Almanach Muzealny 3 (2001): 177-186.

Sowa, Jonna. „Halina Bolesławska (1954-1999).” Szkice Archiwalno-Historyczne 5 (2009): 157-158.

Stelmach, Roman. „Źródła archiwalne do historii franciszkanów-obserwantów na Śląsku w Archiwum Państwowym we Wrocławiu." W Bernardyni na Śląsku w późnym średniowieczu, red. Jakub Kostowski, 77-89. Wrocław: Oficyna Wydawnicza Atut Wrocławskie Wydawnictwo Oświatowe, 2005.

Stępień, Wojciech. „Archiwa państwowe na Słowacji: organizacja, działalność, zasoby.” Teki Archiwalne. Seria Nowa 10 (2009): 47-70.

Szczepańczyk, Joanna. „Józefa Okoniewska - archiwistka Archiwum Książąt Pszczyńskich." Szkice Archiwalno-Historyczne 4 (2008): 70-74.

Szymański Józef. Nauki pomocnicze historii. Warszawa: Wydawnictwo Naukowe PWN, 2009.

Tandecki, Janusz. Archiwa w Polsce w latach 1944-1989: zarys dziejów. Toruń: Wydawnictwo Naukowe Uniwersytetu Mikołaja Kopernika, 2017.

Tomczak, Andrzej. Zarys dziejów archiwów polskich, cz. I-II. Toruń: UMK, 1974-1980.

Wachowiak, Bogdan, Zygmunt Szultka, wyd. Źródła do dziejów ziemi lęborsko-bytowskiej: od statusu lenna polskiego do inkorporacji do Królestwa Pruskiego i integracji z Pomorzem pruskim (1657-1815), t. 1-2. Warszawa: Naczelna Dyrekcja Archiwów Państwowych. Departament Edukacji i Współpracy z Zagranicą, 2011.

Wakuluk, Lidia. „Materiały archiwalne dotyczące okupacji hitlerowskiej w zasobie archiwum inowrocławskiego - wartość badawcza." Ziemia Kujawska 18 (2005): 163-170.

Walichnowski, Tadeusz, red. Stan wojenny $w$ Polsce. Dokumenty i materiały archiwalne 1981-1983. Warszawa: „Comandor” 2001.

Woszczyński, Bolesław, Violetta Urbaniak, red. Źródła archiwalne do dziejów Żydów w Polsce. Warszawa: „DiG”; NDAP, 2001.

Więch-Tchórzewska, Wanda. „Najcenniejsze materiały archiwalne do dziejów Wschodniego Mazowsza i Południowego Podlasia w zespole akt Komisji Rządowej Spraw Wewnętrznych [w AGAD].” W Źródła do dziejów regionu: I Siedlecka Sesja Archiwalna, red. Urszula Głowacka-Maksymiuk, Grzegorz Welik, 83-91. Siedlce: FRBR „Sigillum”; AP, 2002.

Wlezień, Paweł. „Archiwum Zakładowe Małopolskiego Urzędu Wojewódzkiego w Krakowie jako przykład archiwum zbiorczego na szczeblu wojewódzkim." W Archiwa przejściowe i zbiorcze: organizacja i funkcjonowanie, red. Dorota Drzewiecka, Marlena Jabłońska, 89-104. Toruń: Wydawnictwo Naukowe Uniwersytetu Mikołaja Kopernika, 2016. 